(c) American Dairy Science Association, 2004.

\title{
Macromineral Digestion by Lactating Dairy Cows: Estimating Phosphorus Excretion via Manure*
}

\author{
W. P. Weiss and D. J. Wyatt \\ Department of Animal Sciences, \\ Ohio Agricultural Research and Development Center \\ The Ohio State University, Wooster 44691
}

\section{ABSTRACT}

Data from 8 experiments involving 39 diverse dietary treatments and 162 Holstein cows were used to derive equations that estimate manure excretion of $\mathrm{P}$ by lactating dairy cows. Within an experiment, diets were formulated to have similar $\mathrm{P}$ concentrations and to meet or slightly exceed standard recommendations for $P$. The data were generated from total collection digestion trials. The only sources of supplemental $\mathrm{P}$ used were dicalcium phosphate and monosodium phosphate. The concentration of dietary $\mathrm{P}$ ranged from 0.34 to $0.45 \%$ of dry matter (DM). Cows varied in milk production (8 to $59 \mathrm{~kg} / \mathrm{d}$ ), DM intake (12.4 to $30.5 \mathrm{~kg} / \mathrm{d}$ ), and $\mathrm{P}$ intake (45 to $133 \mathrm{~g} / \mathrm{d}$ ). Apparent digestibility of $\mathrm{P}$ averaged $40.4 \%$, fecal output of $\mathrm{P}$ averaged $47 \mathrm{~g} / \mathrm{d}$, and apparent $\mathrm{P}$ retention averaged $4 \mathrm{~g} / \mathrm{d}$. Two equations were derived to estimate excretion of $\mathrm{P}$ via manure ( $\mathrm{g} /$ d): 1) Manure $\mathrm{P}=-2.5+0.64 \times \mathrm{P}$ intake, and 2) Manure $\mathrm{P}=7.5+0.78 \times \mathrm{P}$ intake $-0.702 \times$ Milk; where $\mathrm{P}$ intake is in $\mathrm{g} / \mathrm{d}$ and milk is $\mathrm{kg} / \mathrm{d}$. Both equations were evaluated using literature data, and both equations had acceptable accuracy for field use. The requirements for $\mathrm{P}$ of lactating dairy cows from the National Research Council (NRC) were also evaluated, and for most diets, those requirements were adequate based on retention of $\mathrm{P}$. (Key words: phosphorus, manure, environment)

Abbreviation key: TAR = total absorbable requirement, TAS = total absorbable supply.

\section{INTRODUCTION}

Society is becoming increasingly concerned about the environmental impact of manure and manure nutrients. Excretion of $\mathrm{P}$ via manure is of particular interest because current rules regulating certain dairy

Received November 30, 2003

Accepted February 22, 2004.

Corresponding author: W. P. Weiss; e-mail: weiss.6@osu.edu.

*Salaries and research support provided by state and federal funds appropriated to the Ohio Agricultural Research and Development Center, The Ohio State University. Manuscript No. 41-03AS. farms in the United States are based in part on the quantity of P excreted in manure (EPA, 2003). Accurate methods of estimating excretion of $\mathrm{P}$ by dairy cows would be useful when developing nutrient management programs. The importance of accurate estimates of $\mathrm{P}$ excretion will increase as stricter and more widespread regulations are adopted.

Several experiments have been conducted recently to evaluate excretion of $\mathrm{P}$, milk production, and reproductive efficiency when cows were fed different amounts of P (Wu and Satter, 2000; Wu et al., 2000, 2001, 2003; Knowlton et al., 2001; Knowlton and Herbein, 2002). However, the database available for examining dietary effects on excretion of $\mathrm{P}$ remains limited. With one exception (Knowlton et al., 2001), these experiments varied $\mathrm{P}$ intake by altering the concentration of $\mathrm{P}$ supplement in the diet, and, in 3 experiments (Wu and Satter, 2000; Wu et al., 2000, 2001), the basal diets were essentially the same. In addition to providing data on $\mathrm{P}$ excretion, those studies also showed that the current NRC (2001) requirements for dietary $P$ are adequate or perhaps slightly overestimated. Because of the prevalent use of the NRC, further evaluation of the NRC model using data obtained from more cows fed a wider variety of diets is needed.

The primary objective of this experiment was to develop accurate equations to estimate excretion of $\mathrm{P}$ by dairy cows fed a variety of diets. A secondary objective was to evaluate the adequacy of current NRC (2001) requirements for $\mathrm{P}$ using $\mathrm{P}$ retention data.

\section{MATERIALS AND METHODS}

\section{Calibration Data Set}

Digestibility data from 8 experiments with 39 dietary treatments and 162 cows or cow-periods (when the experiment was a Latin square) were compiled for this analysis. Total collection of feces and urine was used in all experiments to calculate digestibility and quantify excretion of $\mathrm{P}$. Within each experiment, diets were formulated to have equal concentrations of $P$. Brief descriptions of the original experiments are in Table 1, and descriptive statistics about the diets are 
Table 1. Brief description of experiments (Expt) that provided data to generate equations (calibration data set).

\begin{tabular}{|c|c|c|}
\hline Expt & Treatments & $\mathrm{n}^{1}$ \\
\hline 1 & $\begin{array}{l}9 \text { treatments: Orchardgrass or alfalfa silage }(40 \% \text { of } \mathrm{DM}) \text { with } 10,20 \text {, or } 30 \% \text { corn silage } \\
\text { with a corn grain-based concentrate or a byproduct based concentrate (Weiss, 1995) }\end{array}$ & 36 \\
\hline 2 & $\begin{array}{l}4 \text { treatments: High oil or conventional corn silage with and without kernel processing } \\
\text { (Weiss and Wyatt, 2000) }\end{array}$ & 15 \\
\hline 3 & $\begin{array}{l}6 \text { treatments: } 0.1 \text { or } 0.3 \mathrm{mg} / \mathrm{kg} \text { of supplemental Se with } 0,0.2 \text {, or } 0.4 \% \text { added sulfate } \\
\text { (Ivancic and Weiss, 2001) }\end{array}$ & 24 \\
\hline 4 & $\begin{array}{l}4 \text { treatments: Conventional or highly digestible corn silage at } 33 \text { or } 45 \% \text { of diet } \\
\text { (Weiss and Wyatt, 2002) }\end{array}$ & 23 \\
\hline 5 & 1 treatment: $57 \%$ corn silage and $43 \%$ conventional concentrate (Weiss, unpublished) & 5 \\
\hline 6 & $\begin{array}{l}4 \text { treatments: Short or long season corn silage with } 10 \% \text { alfalfa meal pellets or alfalfa hay } \\
\text { (Weiss, unpublished) }\end{array}$ & 16 \\
\hline 7 & $\begin{array}{l}5 \text { treatments: Control diet and diets with } 1.7 \text { or } 3.2 \% \text { supplemental fat from two } \\
\text { different sources (Weiss and Wyatt, 2004) }\end{array}$ & 25 \\
\hline 8 & $\begin{array}{l}3 \text { treatments: Diets with } 25,28 \text {, or } 32 \% \text { NDF in which NDF was increased by replacing } \\
\text { corn grain with byproducts (Beckman, 2003) }\end{array}$ & 18 \\
\hline
\end{tabular}

${ }^{1}$ Number of observations (cows or cow-periods) in each experiment.

in Tables 2 and 3. All experimental protocols were approved by the University Agricultural Animal Care Committee.

\section{Sampling and Analytical Methods}

All experiments were conducted at the Ohio Agricultural Research and Development Center (Wooster) with lactating Holstein cows in their second or greater lactation. The same protocol for total collection of feces and urine was used in all experiments. Briefly, cows were housed in tie stalls designed for total collection of urine and feces for 4 to $6 \mathrm{~d}$, and the amount of feed offered and refused and output of feces, urine, and milk were measured and sampled daily and composited within cow for the period. Urine was kept separate

Table 2. Description of dietary ingredients used in the experiments (39 diets).

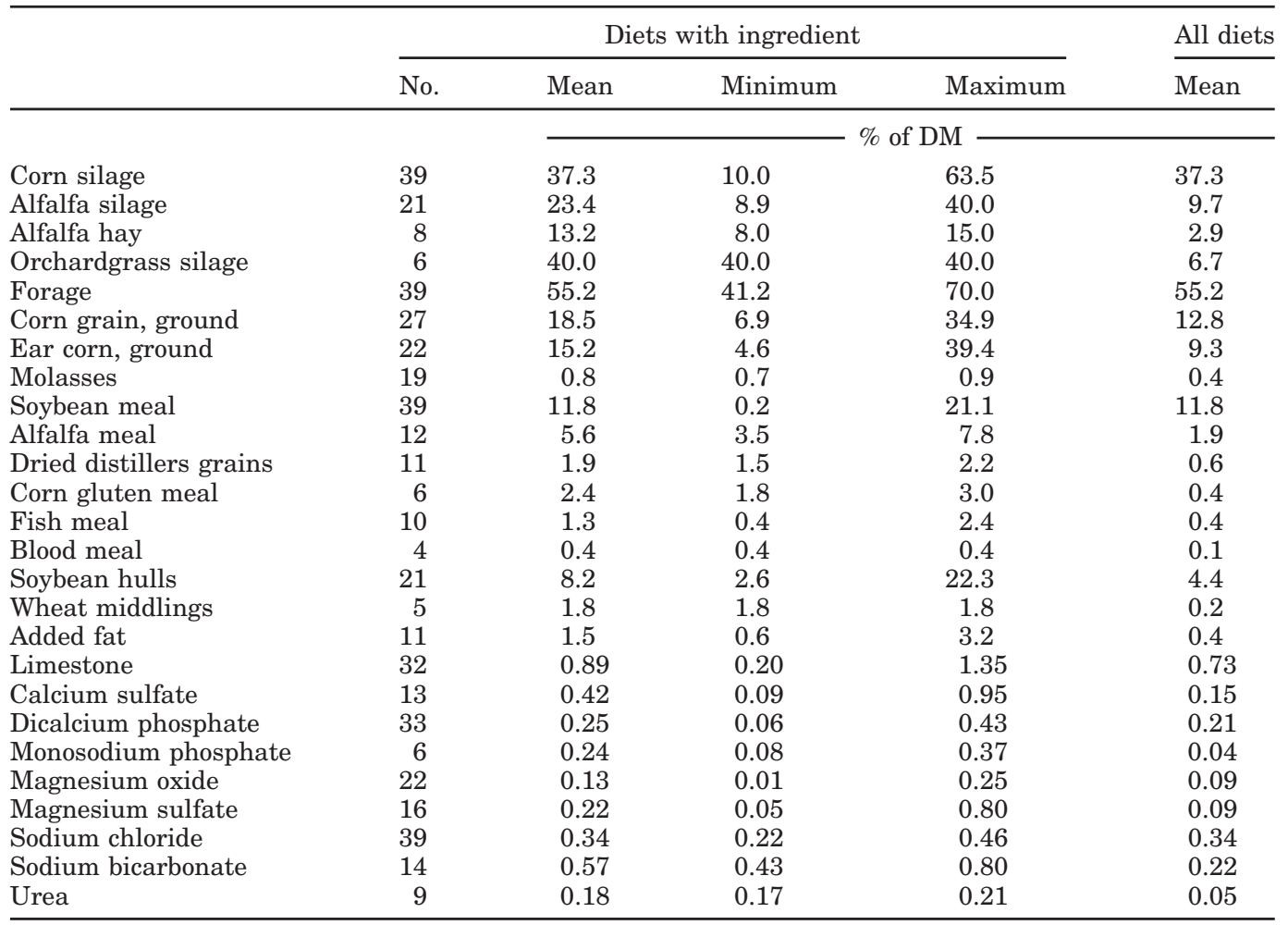


Table 3. Descriptive statistics for the nutrient composition of diets (\% of DM) in the calibration data set (8 experiments, 39 different dietary treatments).

\begin{tabular}{llllc}
\hline Nutrient & Mean & SD & Minimum & Maximum \\
\hline DM & 62.8 & 4.7 & 53.7 & 70.4 \\
CP & 16.7 & 1.1 & 14.8 & 18.5 \\
NDF & 33.9 & 5.8 & 24.7 & 45.5 \\
Calcium & 0.88 & 0.09 & 0.66 & 1.03 \\
Phosphorus & 0.38 & 0.03 & 0.34 & 0.45 \\
Supplemental P, \% of total P & 9.9 & 4.4 & 2.9 & 20.4 \\
Ca:P & 2.3 & 0.3 & 1.8 & 2.9 \\
Magnesium & 0.27 & 0.04 & 0.20 & 0.36 \\
Potassium & 1.60 & 0.51 & 1.07 & 2.65 \\
Sodium & 0.18 & 0.08 & 0.06 & 0.32 \\
\hline
\end{tabular}

from feces using an externally attached cup (Fellner et al., 1988). Treatment effects on $P$ balance were not an original objective in any experiment; however, dried ground feed, orts, and fecal samples were available. Milk and urine samples were no longer available for experiments 1 through 6 , but milk and urine samples from experiments 7 and 8 were assayed for P. Samples of forages and feces were dry-ashed (AOAC, 1990), and concentrates and orts were digested with perchloric acid (AOAC, 1990). Milk and urine samples were digested as described by Timmons et al. (2001). Phosphorus concentrations in all digests were analyzed using an inductively coupled plasma spectrophotometer (AOAC, 1990).

Apparent digestibility of $\mathrm{P}$ was calculated as measured $\mathrm{P}$ intake minus measured fecal output of $\mathrm{P}$ di- vided by intake of $\mathrm{P}$. Apparent $\mathrm{P}$ balance was calculated as measured $\mathrm{P}$ intake minus $\mathrm{P}$ output in feces, milk, and urine. Milk and urinary output of $P$ were estimated for experiments 1 through 6 by multiplying milk or urinary excretion by an estimated concentration of $\mathrm{P}$. The concentration of $\mathrm{P}$ in milk was assumed to be $0.9 \mathrm{~g} / \mathrm{kg}$ of milk (NRC; 2001; Wu et al., 2001; Knowlton and Herbein, 2002). The mean measured concentration of $\mathrm{P}$ in milk from experiment 7 and 8 was $0.092 \%$. The concentration of $\mathrm{P}$ in urine $(\mathrm{g} / \mathrm{kg})$ was estimated as: $(-0.022+0.125 \times \%$ dietary $\mathrm{P})$. That equation was derived by regressing the average urinary $\mathrm{P}$ concentrations on the average dietary $\mathrm{P}$ concentrations reported by Wu et al. (2001). Manure $\mathrm{P}(\mathrm{g} / \mathrm{d})$ was calculated as measured fecal $\mathrm{P}(\mathrm{g} / \mathrm{d})$ plus estimated or measured urinary $\mathrm{P}(\mathrm{g} / \mathrm{d})$.

Table 4. Descriptive statistics of the means from the literature used to evaluate the equations (evaluation data set).

\begin{tabular}{lccc}
\hline & Mean & Minimum & Maximum \\
\hline Experiments with Holstein cows $(\mathrm{n}=54)^{1}$ & & & \\
BW, kg & 629 & 552 & 763 \\
DIM & 91 & 14 & 280 \\
DMI, kg/d & 22.2 & 10.9 & 52.8 \\
Milk yield, kg/d & 37.7 & 10.0 & 0.67 \\
Dietary P, \% of DM & 0.42 & 0.15 & 180 \\
P intake, g/d & 93 & 21 & 119 \\
Fecal P output, g/d & 56 & 13 & 121 \\
Manure P output ${ }^{2}$, g/d & 57 & 14 & 464 \\
Experiments with Jersey cows $(\mathrm{n}=46)^{3}$ & & 316 & 261 \\
BW, kg & 395 & 33 & 16.5 \\
DIM & 143 & 9.8 & 17.9 \\
DMI, kg/d & 12.9 & 4.5 & 0.50 \\
Milk yield, kg/d & 12.8 & 0.18 & 69 \\
Dietary P, \% of DM & 0.35 & 23 & 46 \\
P intake, g/d & 45 & 11 & 46 \\
Fecal P output, g/d & 27 & 12 & \\
Manure P output, g/d & 28 & & \\
\hline
\end{tabular}

${ }^{1}$ Holstein data compiled from published sources (Hibbs and Conrad, 1983; Martz et al., 1990; Morse et al., 1992; Brintrup et al., 1993; Spiekers et al., 1993; Rodriguez, 1998; Wu et al., 2000; Knowlton et al., 2001; Knowlton and Herbein, 2002; Wu et al., 2003). Not all experiments reported BW ( $\mathrm{n}=49$ ) or DIM ( $\mathrm{n}=$ 46).

${ }^{2}$ Measured manure $\mathrm{P}(\mathrm{g} / \mathrm{d})$ was used when available $(\mathrm{n}=26)$ otherwise it was calculated as measured fecal $\mathrm{P}(\mathrm{g} / \mathrm{d})+20 \times(-0.022+0.125 \times \% \mathrm{P}$ in $\operatorname{diet} \mathrm{DM})$.

${ }^{3}$ Jersey data compiled from Hibbs and Conrad (1983). 
Table 5. Descriptive statistics for cows, digestibility, and $\mathrm{P}$ excretion and retention in the calibration data set (8 experiments, 39 dietary treatments, 162 observations).

\begin{tabular}{lcccc}
\hline & Mean & SD & Minimum & Maximum \\
\hline BW, kg & 620 & 60 & 480 & 810 \\
DIM & 186 & 64 & 67 & 272 \\
DMI, kg/d & 20.9 & 3.6 & 12.4 & 30.5 \\
Milk yield, kg/d & 30.4 & 8.5 & 8.0 & 59.0 \\
Fecal DM output, kg/d & 6.9 & 1.5 & 3.5 & 12.3 \\
DM digestibility, \% & 67.1 & 3.4 & 56.1 & 74.7 \\
Urine output, kg/d & 19.6 & 7.0 & 8.4 & 42.6 \\
P intake, g/d & 79 & 17 & 45 & 133 \\
Fecal P output, g/d & 47 & 13 & 18 & 1.00 \\
Fecal P, \% of fecal DM & 0.68 & 0.12 & 18.7 & 85.7 \\
Manure P1, g/d & 47.7 & 11.9 & 9.3 & 75.8 \\
P digestibility, \% & 40.4 & 8 & -16 & 41 \\
P tissue retention, g/d & 4 & & & \\
\hline
\end{tabular}

${ }^{1}$ Measured manure excretion of $\mathrm{P}$ (urinary + fecal $\mathrm{P}$ ) was used when available otherwise manure $\mathrm{P}$ excretion was estimated as measured fecal P output + [measured urine output $(\mathrm{kg} / \mathrm{d}) \times(-0.022+0.125 \times$ $\% \mathrm{P}$ in $\operatorname{diet} \mathrm{DM})]$.

\section{Evaluation Data Set}

Data were compiled from published studies that measured intake and excretion of $\mathrm{P}$ by lactating Holstein and Jersey cows (Table 4). Six studies (28 means) measured fecal and urinary excretion of $\mathrm{P}$ from Holstein cows (Hibbs and Conrad, 1983; Martz et al., 1990; Morse et al., 1992; Rodriguez, 1998; Knowlton et al., 2001; Knowlton and Herbein, 2002), 5 studies (26 means) reported only fecal excretion of $\mathrm{P}$ by Holstein cows (Brintrup et al., 1993; Spiekers et al., 1993; Wu et al., 2000, 2003), and one paper (46 means) reported measured fecal and urinary excretion of $\mathrm{P}$ from Jersey cows (Hibbs and Conrad, 1983). Urinary excretion of $\mathrm{P}$ was estimated as described above for the 26 means without measured urinary excretion of $P$.

\section{NRC Evaluation}

Diet formulations and actual cow data (DMI, milk yield, milk fat percentage, milk protein percentage, $\mathrm{BW}$, and days pregnant) were used as inputs into the NRC (2001) model for each cow in the calibration data set. Measured P concentrations for the forages were used, but the concentration of $\mathrm{P}$ was not measured for each individual concentrate ingredient (concentration of $\mathrm{P}$ in the entire grain mix was assayed). The $\mathrm{P}$ concentration of feedstuffs used in the concentrate mix (but not the sources of supplemental P) was adjusted slightly so that the calculated concentration of $\mathrm{P}$ in the concentrate mix equaled the measured concentration. The absorption coefficients for $\mathrm{P}$ in the NRC model were used. The model was used to calculate the difference between total absorbable supply (TAS) and total absorbable requirement (TAR) for $\mathrm{P}$ for each cow, and those values were averaged for each diet.

\section{Statistical Analyses}

The calibration data set was used to derive equations. Relationships among variables of interest were quantified using PROC MIXED (SAS, 1999) with experiment (trial) included as a random class effect (StPierre, 2001). The concentration of fecal P (\% of DM), excretion of fecal $\mathrm{P}(\mathrm{g} / \mathrm{d})$, apparent digestibility of $\mathrm{P}$ $(\%)$, excretion of $\mathrm{P}$ via manure $(\mathrm{g} / \mathrm{d})$ and apparent retention of $\mathrm{P}(\mathrm{g} / \mathrm{d})$ were the dependent variables evaluated. The primary independent variable was intake of $\mathrm{P}(\mathrm{g} / \mathrm{d})$. Analyses were conducted using individual observations ( $n=162)$. Trial-adjusted data were calculated as described by St-Pierre (2001). The equations were then evaluated using the evaluation data set. Bias was determined by regressing residuals (observed mean minus predicted values) on predicted values after the mean of the predicted values was subtracted (St-Pierre, 2003). The intercept is an estimate of overall bias, and the slope is an estimate of linear bias.

\section{RESULTS AND DISCUSSION}

A variety of diets are represented in the calibration data set, but all diets contained corn silage, dry ground corn grain, and soybean meal (Table 2). Inclusion of other ingredients varied among treatments. Corn silage was the predominant forage in 27 diets, and no data are from diets in which hay crop forage was the sole forage fed. The only sources of supplemental $\mathrm{P}$ used were dicalcium phosphate ( $85 \%$ of the diets) and monosodium phosphate ( $15 \%$ of the diets). Dietary concentrations of $\mathrm{P}$ ranged from 0.34 to $0.45 \%$ of $\mathrm{DM}$, and on average about $10 \%$ of the total $\mathrm{P}$ was provided by a $\mathrm{P}$ supplement (Table 3 ). Milk production, BW, 


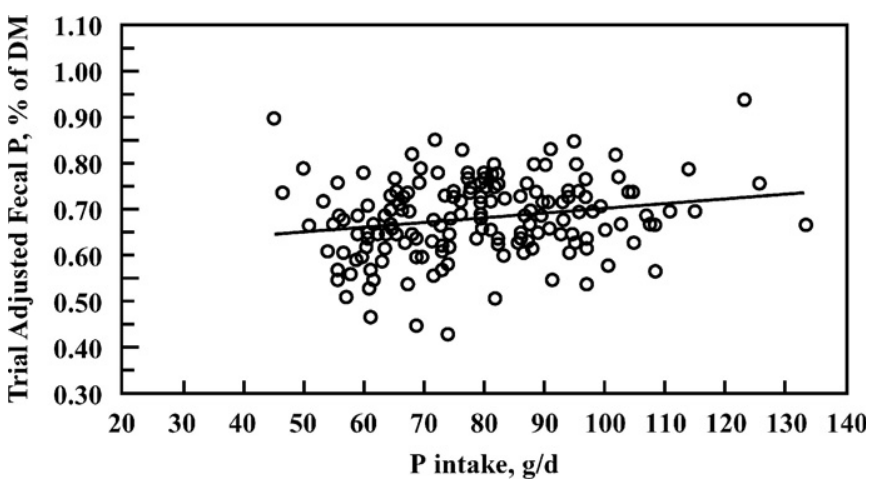

Figure 1. Relationship between $\mathrm{P}$ intake and concentration of $\mathrm{P}$ in feces $(\mathrm{n}=162$ cows $)$. The solid line is $\mathrm{Y}=0.59+0.0006 \mathrm{X}(P<0.06)$.

DIM, and DMI varied widely among cows (Table 5), but no cows less than 60 DIM are represented. Apparent digestibility of $\mathrm{P}$ for individual cows ranged from 9 to $76 \%$ and apparent tissue retention of $\mathrm{P}$ ranged from -16 to $41 \mathrm{~g} / \mathrm{d}$ (Table 5 ). The wide range in these values is caused by diet (range in treatment means for $\mathrm{P}$ digestibility and tissue retention were 20 to $56 \%$ and -5 to $15 \mathrm{~g} / \mathrm{d}$, respectively), cow variation, and error.

\section{Fecal Phosphorus Concentration}

The concentration of fecal $\mathrm{P}(\%$ of $\mathrm{DM})$ increased linearly $(P<0.06)$ as intake of $\mathrm{P}$ increased (Figure 1$)$. However, the concentration of fecal $\mathrm{P}$ was relatively insensitive to changes in intake of $\mathrm{P}$. Based on the observed relationship, a doubling of $\mathrm{P}$ intake from 55 to $110 \mathrm{~g} / \mathrm{d}$ would result in an expected increase of only $6 \%$ in fecal P concentration. Wu et al. (2001) reported a strong relationship between $\mathrm{P}$ intake and fecal $\mathrm{P}$ concentration. The slope for their equation was more than 20 times greater than the slope in Figure 1. The concentration of $\mathrm{P}$ in feces is a function of fecal excretion of both P and DM. In the Wu et al. (2001) study, DMI was similar among treatments, and intake of $P$ was increased by replacing a small portion of beet pulp with monosodium phosphate. Therefore, output of fecal DM was probably similar among treatments. Across treatments, the increased intake of $\mathrm{P}$ would have been voided in the same quantity of fecal DM, thereby increasing fecal $\mathrm{P}$ concentration. In our data set, DMI and DM digestibility varied among treatments, therefore excretion of fecal DM also varied. When diets differed in digestibility of DM and when intake of $\mathrm{P}$ varied mainly as a function of DMI, the concentration of $\mathrm{P}$ in feces could not be estimated with acceptable precision for field applications.

\section{Fecal Phosphorus Excretion}

Excretion of $\mathrm{P}$ via feces ( $\mathrm{g} / \mathrm{d}$ ) is a function of DMI, intake of $\mathrm{P}$, and the true digestibility of $\mathrm{P}$. Fecal $\mathrm{P}$ is composed of an endogenous fraction and a truly indigestible fraction. A portion of the endogenous fraction is considered an inevitable loss and is estimated as $0.8 \mathrm{~g} / \mathrm{kg}$ of DMI (NRC, 2001). The other portion of the endogenous fraction is digested $\mathrm{P}$ that is secreted into the gut to maintain $\mathrm{P}$ homeostasis and is a function of intake of absorbable $\mathrm{P}$ relative to requirements for absorbed P. In the calibration data set, variation in $\mathrm{P}$ intake among cows within an experiment was caused by differences in DMI among cows. Variation in intake of $\mathrm{P}$ across studies was caused by differences in DMI among cows and differences in dietary concentrations of $\mathrm{P}$. The effects of DMI cannot be separated from those caused by intake of $\mathrm{P}$. Intake of $\mathrm{P}$, rather than DMI, was used as the independent variable because intake of $\mathrm{P}$ incorporates both DMI and dietary $P$ concentration. Fecal excretion of $P(g / d)$ increased linearly $(P<0.001)$ as intake of $\mathrm{P}(\mathrm{g} / \mathrm{d})$ increased:

$$
\begin{aligned}
\text { Fecal } \mathrm{P}=-2.3 & ( \pm 4.2)+0.63( \pm 0.046) \\
& \times \mathrm{P} \text { intake }
\end{aligned}
$$

Fecal excretion of $\mathrm{P}(\mathrm{g} / \mathrm{d})$ also was negatively related $(P<0.01)$ to apparent DM digestibility $(\%)$ :

$$
\text { Fecal } \begin{aligned}
P= & 139.8( \pm 15.7)-1.38( \pm 0.23) \\
& \times \text { DM digestibility }
\end{aligned}
$$

The relationship between DM digestibility and fecal excretion of $\mathrm{P}$ was independent of DMI and intake of $\mathrm{P}$ and was caused mainly by a positive relationship $(P<0.01)$ between DM digestibility $(\%)$ and apparent digestibility of $\mathrm{P}(\%)$ :

$$
\begin{gathered}
\text { P Digestibility }=-65.7( \pm 12.7)+1.58 \\
( \pm 0.19) \times \text { DM digestibility }
\end{gathered}
$$

Actual DM digestibility will not be known under field conditions, therefore its use for estimating onfarm excretion of $\mathrm{P}$ has limited value. However, these results suggest that feeding highly digestible diets reduce excretion of $\mathrm{P}$ by dairy cows.

Many studies (Morse et al., 1992; Wu et al., 2001; Knowlton and Herbein, 2002) have reported that apparent digestibility of $\mathrm{P}$ decreased with increasing intake of $\mathrm{P}$. However in our data set, apparent digestibility of $\mathrm{P}$ was not affected $(P>0.35)$ by intake of $\mathrm{P}$ (data not shown). In the previous studies, intake of $\mathrm{P}$ was varied among treatments by addition of varying amounts of supplemental P. Within experiments, DMI 


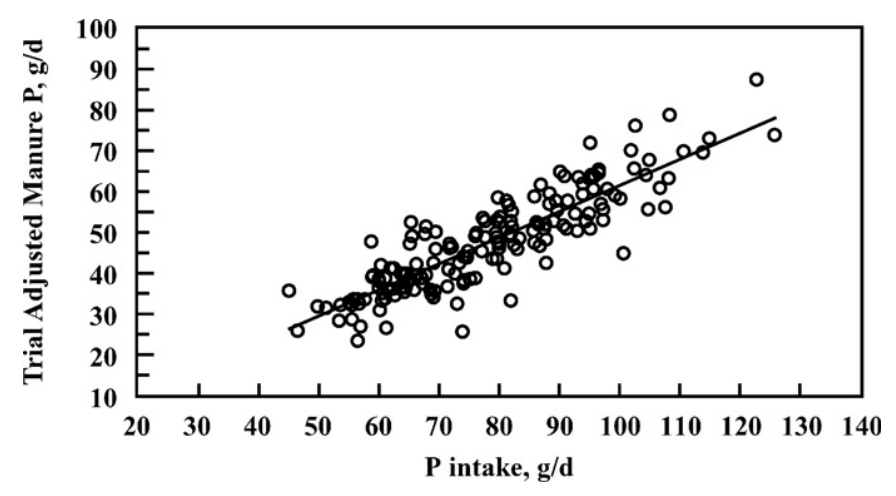

Figure 2. The relationship between excretion of $\mathrm{P}$ via manure and intake of $\mathrm{P}$ (calibration data set, $\mathrm{n}=162$ ). The solid line is: $\mathrm{Y}=$ $-2.5+0.64 \mathrm{X}(P<0.01) ; \mathrm{SE}_{\text {Residual }}=4.1 \mathrm{~g} / \mathrm{d} \mathrm{SE}_{\text {Trial }}=17.4 \mathrm{~g} / \mathrm{d}$.

and milk yields were similar among treatments. Therefore, to maintain $\mathrm{P}$ homeostasis, cows that were fed diets with elevated concentrations of $\mathrm{P}$ increased fecal excretion of the unneeded $\mathrm{P}$ and that reduced apparent digestibility of $\mathrm{P}$. In our data set, intake of $P$ varied mostly because of variation in DMI, and DMI varied largely because of differences in milk yield.

\section{Estimating Manure Excretion of $\mathbf{P}$}

Urine samples were not available from most experiments in the calibration set, therefore estimated urinary excretion of $\mathrm{P}$ had to be used to calculate manure excretion of $\mathrm{P}$ for 119 of the 162 observations. Estimated urinary excretion of $\mathrm{P}$ ranged from 0.2 to 1.4 $\mathrm{g} / \mathrm{d}$ in the calibration data set. Published values for daily excretion of $\mathrm{P}$ via urine range from about 0.3 to $1.6 \mathrm{~g} / \mathrm{d}$ for dairy cows (Jersey and Holstein) when fed diets containing $<0.5 \% \mathrm{P}$ (Hibbs and Conrad, 1983; Knowlton et al., 2001; Knowlton and Herbein, 2002). When cows were fed diets with $0.67 \% \mathrm{P}$ (greater than any concentration in our data set) excretion of urinary $\mathrm{P}$ ranged from 3.2 to $6.1 \mathrm{~g} / \mathrm{d}$ (Knowlton and Herbein, 2002). In most studies, measured urinary excretion of $\mathrm{P}$ was $<5 \%$ of the $\mathrm{P}$ excreted in feces. The use of estimated urinary $\mathrm{P}$ excretion to calculate excretion of $P$ via manure should not affect the accuracy of the derived equations.

The best-fitting equation for estimating manure excretion of $P(g / d)$ used intake of $P(g / d)$ (Figure 2):

$$
\begin{aligned}
\text { Manure } \mathrm{P}=- & -2.5( \pm 4.1)+0.64( \pm 0.04) \\
& \times \mathrm{P} \text { intake }
\end{aligned}
$$

An alternative approach to estimate manure excretion of P proposed by Van Horn et al. (1994) and evaluated by Beede and Davidson (1999) was to subtract the amount of $\mathrm{P}$ secreted in milk (g/d) from intake of $P$ (g/d) (equation [5]). Secretion of $P$ via milk can be estimated by assuming milk contains $0.9 \mathrm{~g} / \mathrm{kg}$ of $\mathrm{P}$.

$$
\begin{gathered}
\text { Manure } \mathrm{P}=\mathrm{P} \text { intake } \\
-(\text { Milk yield, } \mathrm{kg} \times 0.9)
\end{gathered}
$$

Manure P excretion was estimated for the 162 observations using equation [5] and compared with measured values (data not shown). This method of estimating manure excretion of $\mathrm{P}$ had a mean $(-3.8 \mathrm{~g} / \mathrm{d}, P<$ $0.01)$ and linear bias $(-0.15 ; P<0.01)$. These biases are biologically real and occurred because an implicit assumption of equation [5] is that body retention of $\mathrm{P}$ is 0 , which is not always true.

In this data set, $\mathrm{P}$ retention averaged $4 \mathrm{~g} / \mathrm{d}$ (Table 5). Tissue retention of $P$ would be expected because of fetal growth (85\% of the cows were pregnant, average gestation day for all cows $=91$ ), and average BW was less than mature weight for Holsteins, meaning that some growth was probably occurring. Retention of $\mathrm{P}$ increased as $\mathrm{P}$ intake increased and as the difference between intake of $\mathrm{P}$ and $\mathrm{P}$ secreted in milk increased (data not shown). The equation relating retention of $\mathrm{P}$ $(\mathrm{g} / \mathrm{d}$ ) with the quantity $(\mathrm{g} / \mathrm{d}$ ) of $\mathrm{P}$ available for retention (i.e., $\mathrm{P}$ consumed minus that secreted in milk) was:

$$
\begin{gathered}
\mathrm{P} \text { retention }=-7.5( \pm 2.8)+0.22( \pm 0.05) \\
\times(\mathrm{P} \text { available for retention })
\end{gathered}
$$

Because the bias in equation [5] is caused by $\mathrm{P}$ retention, combining equations [5] and [6] should result in an unbiased estimate of manure $\mathrm{P}$ excretion. Algebraic reduction of equation [5] plus equation [6] resulted in the final equation for estimating manure $P(g / d)$ using intake of $\mathrm{P}(\mathrm{g} / \mathrm{d})$ and milk yield $(\mathrm{kg} / \mathrm{d})$ :

$$
\begin{gathered}
\text { Manure } P=7.5+0.78 \times \mathrm{P} \text { intake } \\
-0.702 \times \text { Milk }
\end{gathered}
$$

\section{Equation Evaluation}

The accuracy of equations [4] and [7] for estimating daily excretion of $\mathrm{P}$ was evaluated using the evaluation data set (Table 4$)$. No mean bias $(P>0.60)$ was observed for equation [4] for the combined evaluation set or when the evaluation set was broken down into Holstein and Jersey data (Figure 3). However, linear biases $(P<0.01)$ were found for the Holstein and combined data set ( 0.14 and 0.12 , respectively). At the highest intake of $P$ in the validation set $(180 \mathrm{~g} / \mathrm{d})$, the value estimated using equation [4] was $6 \%$ lower than measured excretion of $\mathrm{P}$ via manure. The standard 


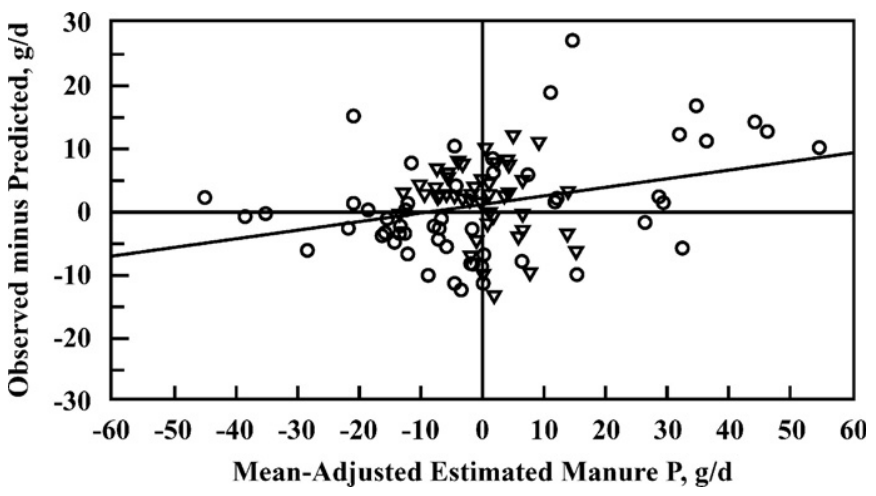

Figure 3. Measured excretion of $\mathrm{P}$ in manure (evaluation data set) minus excretion of $\mathrm{P}$ estimated using equation [4] vs. meanadjusted estimated (equation [4]) manure excretion of P. Mean estimated manure excretion by Holstein $(56.3 \mathrm{~g} / \mathrm{d})$ and Jerseys $(26.0 \mathrm{~g} /$ d) was subtracted from the estimated values on the $\mathrm{X}$ axis. Circles represent treatment means from Holstein cows $(n=54)$ and triangles represent treatment means from Jersey cows $(n=46)$. The solid line represents the regression for the combined data set $(\mathrm{Y}=1.15+$ $0.135 \mathrm{X})$. The intercept (mean bias) was not different from $0(P>$ $0.60)$, but the slope (linear bias) was greater than $0(P<0.01)$

deviations of the residuals for the full validation set, for the Holstein data, and the Jersey data were 7.1, 8.8 , and $5.4 \mathrm{~g} / \mathrm{d}(\mathrm{CV}=16.5,14.6$, and $19.5 \%)$, respectively. The precision of an equation cannot be greater than the precision in measurement. Reported standard errors of means from experiments (Holstein data) that measured manure excretion of $\mathrm{P}$ ranged from 3 to $7 \mathrm{~g} / \mathrm{d}$ (Knowlton et al., 2001; Knowlton and Herbein, 2002; Morse et al., 1992).

For the full-evaluation data set, equation [7] had no mean or linear biases $(P>0.30)$ (Figure 4$)$. The Jersey

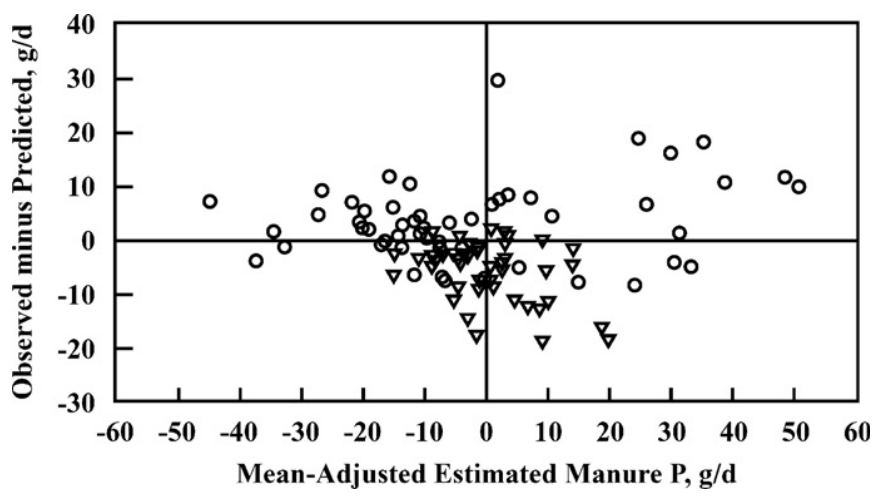

Figure 4. Measured excretion of $\mathrm{P}$ in manure (evaluation data set) minus excretion of $\mathrm{P}$ estimated using equation [7] vs. meanadjusted estimated (equation [7]) manure excretion of P. Mean estimated manure excretion by Holstein $(53.6 \mathrm{~g} / \mathrm{d})$ and Jerseys $(33.6 \mathrm{~g} /$ d) was subtracted from the estimated values on the $\mathrm{X}$ axis. Circles represent treatment means from Holstein cows $(n=54)$ and triangles represent treatment means from Jersey cows $(\mathrm{n}=46)$. The combined data set had no mean or linear bias $(P>0.30)$.

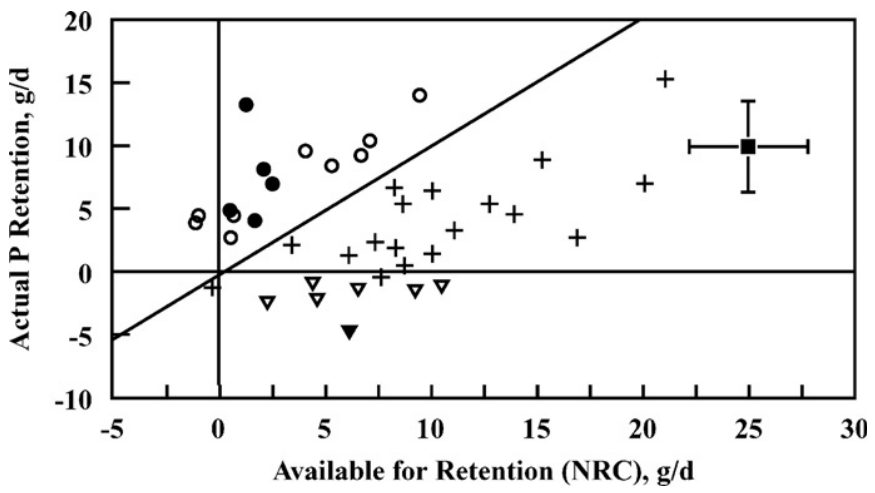

Figure 5. Comparison between $\mathrm{P}$ available for retention as calculated by NRC (2001) and actual P retention (g/d) for 39 treatment means. The diagonal line depicts unity (i.e., actual retention equaled the amount available to be retained as calculated by NRC. Points above the diagonal (circles) represent diets in which retention was greater than the amount available for retention per NRC. The solid circles are more than $1 \mathrm{SE}$ unit from the diagonal line. Crosses represent diets that are possible based on NRC. Triangles represent diets in which actual $\mathrm{P}$ retention was negative whereas NRC estimated adequate $\mathrm{P}$ to at least maintain $\mathrm{P}$ balance (retention $=0$ ). The solid triangle is more than $1 \mathrm{SE}$ unit from 0 retention. The vertical and horizontal bars associated with the square are the mean SE for measured $\mathrm{P}$ retention (vertical) and $\mathrm{P}$ available for retention as calculated by NRC (horizontal).

data set had a mean bias of $-5.8 \mathrm{~g} / \mathrm{d}(P<0.01)$ and a linear bias of $0.28(P<0.01)$, and the Holstein data set had a mean bias of $3.3 \mathrm{~g} / \mathrm{d}(P<0.05)$, but no linear bias $(P>0.15)$. Differences in biases between the breeds could reflect true breed differences, but they also could be caused by numerous other factors including diet, milk production, and stage of lactation. The Jersey data are from experiments conducted more than $20 \mathrm{yr}$ ago and milk production and DMI are low based on current standards. The standard deviations of the residuals for the full, Holstein, and Jersey data sets were $8.1,7.4$, and $5.4 \mathrm{~g} / \mathrm{d}$.

Equations [4] or [7] can be used to estimate manure excretion of $\mathrm{P}$ by lactating dairy cows. Based on bias, equation [7] is slightly better than equation [4], but based on standard deviations of residuals, equation [4] is slightly better than equation [7].

\section{Evaluation of NRC model}

A simple and effective method of minimizing excretion of $\mathrm{P}$ is to feed diets that meet, but do not exceed, the $\mathrm{P}$ requirement of the cow. Phosphorus retention data were used to evaluate the NRC (2001) recommendations for $\mathrm{P}$. If measured retention of $\mathrm{P}$ was negative but the NRC model estimated that the difference between TAS and TAR was $\geq 0$, then the model is either overestimating absorbable supply or underestimating requirement. The result being that cows fed per NRC 
estimates would be deficient in P. If measured retention of $\mathrm{P}$ was greater than the difference between TAS and TAR, then the model is either underestimating absorbable supply or overestimating the requirement for P. The result being that diets formulated per NRC recommendations would contain excess P. Measured retention of $\mathrm{P}$ that is $\geq 0$ and less than the difference between TAS and TAR are possible (although not necessarily accurate) based on NRC. Average retention of $\mathrm{P}$ was negative for cows fed 7 of the 39 diets evaluated even though the NRC model estimated adequate dietary $\mathrm{P}$ (Figure 5), but retention of $\mathrm{P}$ from only one of those 7 diets was statistically less than 0 . Average retention of $\mathrm{P}$ was greater than the amount of $\mathrm{P}$ available for retention as calculated by NRC for cows fed 14 diets, but only 5 of those 14 means were statistically greater than the amount available for retention calculated by NRC. This analysis suggests that following the recommendations for $\mathrm{P}$ from $\mathrm{NRC}$ will rarely result in a deficiency of $\mathrm{P}$.

The $\mathrm{P}$ retention data offers additional support for the NRC (2001) model. At $0 \mathrm{~g} / \mathrm{d} \mathrm{P}$ retention, estimated average manure $\mathrm{P}$ excretion was $34 \mathrm{~g} / \mathrm{d}$. That value represents inevitable fecal loss, inevitable urinary loss, and truly indigestible P. The NRC (2001) estimates inevitable urinary loss of $\mathrm{P}$ as $0.002 \mathrm{~g} / \mathrm{kg}$ of BW and inevitable fecal loss as $0.8 \mathrm{~g} / \mathrm{kg}$ of DMI. Using overall means (Table 5) and NRC equations, average inevitable urinary loss was $1.2 \mathrm{~g} / \mathrm{d}$, and mean inevitable fecal loss was $16.7 \mathrm{~g} / \mathrm{d}$. The average absorption coefficient for $\mathrm{P}$ for these diets (based on values in $\mathrm{NRC}$ ) was 0.7 . Mean intake of $\mathrm{P}$ was $55 \mathrm{~g} / \mathrm{d}$ at $0 \mathrm{~g} / \mathrm{d}$ retention of $\mathrm{P}$ (data not shown), therefore, average truly indigestible $\mathrm{P}$ would be $16.5 \mathrm{~g} / \mathrm{d}$ (i.e., $55 \times 0.3$ ). The sum of those 3 values $(1.2+16.7+16.5=34.4 \mathrm{~g} /$ d) obtained from NRC equations is essentially equal to the experimentally measured expected value (34 g/d).

\section{CONCLUSIONS}

Two equations that use input variables usually available on-farm (i.e., milk yield and intake of $\mathrm{P}$ ) were developed to estimate manure excretion of $\mathrm{P}(\mathrm{g} / \mathrm{d})$ for lactating dairy cows. The equations were evaluated using a diverse set of data from Holstein and Jersey cows, and both equations have adequate precision and accuracy for on-farm use. Based on measured retention of P, diets formulated per the NRC (2001) model rarely resulted in a deficiency of $\mathrm{P}$.

\section{REFERENCES}

Association of Official Analytical Chemists. 1990. Official Methods of Analysis. Vol. 1. 15th ed. AOAC, Arlington, VA.
Beckman, J. L. 2003. Effect of starch concentration on measures of fiber digestibility by lactating dairy cows. M.S. Thesis. The Ohio State Univ., Columbus.

Beede, D. K., and J. A. Davidson. 1999. Phosphorus: Nutritional management for Y2K and beyond. Pages 51-97 in Tri-State Dairy Nutr. Conf., Ft. Wayne, IN.

Brintrup, R., T. Mooren, U. Meyer, H. Spiekers, and E. Pfeffer. 1993. Effects of two levels of phosphorous intake on performance and faecal phosphorus excretion of dairy cows. J. Anim. Physiol. Anim. Nutr. 69:29-36.

EPA. 2003. National pollutant discharge elimination system permit regulation and effluent limitation guidelines and standards for concentrated animal feeding operations (CAFOs): Final Rule. Federal Register 68 (No. 29) 7175-7274 (Feb. 12).

Fellner, V., M. F. Weiss, A. T. Belo, R. L. Belyea, F. A. Martz, and A. H. Orma. 1988. Urine cup for collection of urine from cows. J. Dairy Sci. 71:2250-2255.

Hibbs, J. W., and H. R. Conrad. 1983. The relationship of calcium and phosphorus intake and digestion and the effect of vitamin $\mathrm{D}$ feeding on utilization of calcium and phosphorus by lactating cows. Ohio Agric. Res. Dev. Center Res. Bull. 1150:1-26.

Ivancic, J., and W. P. Weiss. 2001. Effect of dietary sulfur and selenium concentrations on selenium balance of lactating Holstein cows. J. Dairy Sci. 84:225-232.

Knowlton, K. F., and J. H. Herbein. 2002. Phosphorus partitioning during early lactation in dairy cows fed diets varying in phosphorus content. J. Dairy Sci. 85:1227-1236.

Knowlton, K. F., J. H. Herbein, M. A. Meister-Weisbarth, and W. A. Wark. 2001. Nitrogen and phosphorus partitioning in lactating Holstein cows fed different sources of dietary protein and phosphorus. J. Dairy Sci. 84:1210-1217.

Martz, F. A., A. T. Belo, M. F. Weiss, R. L. Belyea, and J. P. Goff. 1990. True absorption of calcium and phosphorus from alfalfa and corn silage when fed to lactating cows. J. Dairy Sci. 73:1288-1295.

Morse, D., H. H. Head, C. J. Wilcox, H. H. Van Horn, C. D. Hissem, and B. Harris, Jr. 1992. Effects of concentration of dietary phosphorus on amount and route of excretion. J. Dairy Sci. 75:3039-3049.

National Research Council. 2001. Nutrient Requirements of Dairy Cattle. 7th rev. ed. Natl. Acad. Press, Washington, DC.

Rodriguez, L. A. 1998. Periparturient responses of cows fed varying dietary cation-anion differences and calcium contents prepartum. Ph.D. Diss., Michigan State Univ., East Lansing.

SAS. 1999. SAS/STAT User's Guide, Version 8. SAS Institute Inc., Cary, NC.

Spiekers, H., R. Brintrup, M. Balmelli, and E. Pfeffer. 1993. Influence of dry matter intake on faecal phosphorous losses in dairy cows fed rations low in phosphorous. J. Anim. Physiol. Anim. Nutr. 69:37-43.

St-Pierre, N. R. 2001. Invited review: Integrating quantitative findings from multiple studies using mixed model methodology. J. Dairy Sci. 84:741-755.

St-Pierre, N. R. 2003. Reassessment of biases in predicted nitrogen flows to the duodenum by NRC 2001. J. Dairy Sci. 86:344-350.

Timmons, J. S., W. P. Weiss, D. L. Palmquist, and W. J. Harper. 2001. Relationships among dietary roasted soybeans, milk components, and spontaneous oxidized flavor of milk. J. Dairy Sci. 84:2440-2449.

Van Horn, H. H., A. C. Wilkie, W. J. Powers, and R. A. Nordstedt. 1994. Components of dairy manure management systems. J. Dairy Sci. 77:2008-2030.

Weiss, W. P. 1995. Full lactation response of cows fed diets with different sources and amounts of fiber and ruminal degradable protein. J. Dairy Sci. 78:1802-1814.

Weiss, W. P., and D. J. Wyatt. 2000. Effect of oil content and kernel processing of corn silage on digestibility and milk production by dairy cows. J. Dairy Sci. 83:351-358.

Weiss, W. P., and D. J. Wyatt. 2002. Effects of feeding diets based on silage from corn hybrids that differed in concentration and in vitro digestibility of neutral detergent fiber to dairy cows. J. Dairy Sci. 85:3462-3469. 
Weiss, W. P., and D. J. Wyatt. 2004. Digestible energy values of fat supplements when fed to lactating dairy cows. J. Dairy Sci. $87: 1446-1454$

Wu, Z., and L. D. Satter. 2000. Milk production and reproductive performance of dairy cows fed two concentrations of phosphorus for two years. J. Dairy Sci. 83:1052-1063.

Wu, Z., L. D. Satter, A. J. Blohowiak, R. H. Stauffacher, and J. H. Wilson. 2001. Milk production, estimated phosphorus excretion, and bone characteristics of dairy cows fed different amounts of phosphorus for two or three years. J. Dairy Sci. 84:1738-1748.

Wu, Z., L. D. Satter, and R. Sojo. 2000. Milk production, reproductive performance, and fecal excretion of phosphorus by dairy cows fed three amounts of phosphorus. J. Dairy Sci. 83:1028-1041.

Wu, Z., S. K. Tallam, V. A. Ishler, and D. D. Archibald. 2003. Utilization of phosphorus in lactating cows fed varying amounts of phosphorus and forage. J. Dairy Sci. 86:3300-3308. 